International Journal of Agriculture, Environment and Bioresearch

Vol. 5, No. 06; 2020

ISSN: $2456-8643$

\title{
DEVELOPMENT OF THE ASSIMILATION APPARATUS OF CHERRIES AND SWEET CHERRIES GROWN ON CLONAL ROOTSTOCKS IN CONNECTION WITH CROWN FORMS
}

\author{
Khalmirzaev Dilmurod Kamilovich, Yenileyev Najdat Shavkatovich and Abdikayumov Zaynilabiddin \\ Abduvokhidovich \\ Department of the Fruit Growing and Viticulture, Tashkent State Agrarian University, 100140, Universitet street, 2 , \\ Tashkent region, Uzbekistan \\ https://doi.org/10.35410/IJAEB.2020.5587
}

\begin{abstract}
The scientific article presents the results of study on the influence of vegetatively propagated low-growing rootstocks and types of artificial forms of crown cherry and sweet cherry on the development of the leaf apparatus of such varieties of cherry Shubinka, Podbelskaya and Shpanka Chernaya (black), sweet cherry Bahor, Revershon and Drogan Zheltaya (yellow). Research has shown that the formation of leaves and the development of the assimilation apparatus of both a single tree and a unit of garden area significantly depends on the genetic characteristics of the variety, the selected rootstock when growing planting material, as well as the method of crown formation. Maximum conditions for the development of the assimilation surface of the cherry variety Shpanka Chernaya (black) are provided on the VVA-1 rootstock when forming a crown of the fruit wall type with five-skeletal branches left in the aboveground part -39.01 thousand $\mathrm{m} 2 /$ ha. In the sweet cherry variety Revershon, the largest assimilation surface - 57.90 thousand $\mathrm{m} 2$ /ha was observed on the rootstock VSL-2 (Krymskaya-5) when using the KGB crown shape (Kim Green Bush). As a result of the conducted research, it was found that the optimal crown system for cherry and sweet cherry varieties is the five-skeletal wall. In this case, the leaf activity index of plants reaches 3.7-4.4 $\mathrm{m} 2$ per crown projection area.
\end{abstract}

Keywords: Cherry, sweet cherry, density, variety, leaf, area, crown, formation, index, projection, chlorophyll.

\section{INTRODUCTION}

Currently, the main method of growing cherries and sweet cherries in production conditions is sparse placement of trees with a rounded crown shape according to the schemes of $5 \times 5$ and $6 \times 5$ meters. The disadvantages of this method of placement include the irrational use of the food area, the late entry of plantings into the time of commercial fruiting, low yield, inconveniences for caring for plants due to the large size of the crowns, and others.

Fruit stands are divided into the following types according to the density of standing in the garden: semi-intensive with a planting density of up to 1000 trees/ha, intensive-with a density of 1000-2500 trees/ha, and super-intensive polycyclic type - 10,000 or more trees per hectare [1, 2, 3]. 
The yield of intensive cherry and sweet cherry plantations on clonal rootstocks with a plant density of up to $1250 \mathrm{pcs} / \mathrm{ha}$ can reach 150-200 c/ha or higher. Even in unfavorable environmental situations, such plantings provide commercial yields of up to $30 \mathrm{c} / \mathrm{ha}$, i.e., in technological terms, they are an insurance link in the system of stone fruit production $[4,5,6]$.

The tendency to maintain gardens with compacted tree placement schemes can be seen in many works of scientists. From which it can be seen that an increase in the density of planting cherries and sweet cherries leads to an increase in yield by an average of 2 times. But it is possible to compact plantings not without limits. When thickening up to 4 meters in the aisle and 2 meters in a row, the cherry tree crowns quickly close, free passage between the trees practically disappears, tillage in the aisles becomes impossible, and the light regime deteriorates so much that it leads to a decrease in yield. Therefore, when creating gardens with dense plant placement, increased requirements are imposed primarily on the structure of the crown.

Currently, the issue of forming the crown of cherry and sweet cherry trees in compacted plantings is extremely relevant. By forming, you can adjust the size of the crown, normalize the crop and adjust the illumination inside the crown, which makes it easier to harvest and care for the garden.

\section{MATERIALS AND METHODS}

The study was conducted in 2016-2019 at the information and consultation center (Extension center) at the Tashkent state agrarian University. The area of the experimental plot is 0.25 ha. The scheme of planting of trees is $4 \times 4$ meters.

As an object of research, the varieties of cherry Podbelskaya, Shubinka and Shpanka Chernaya (black), varieties of sweet cherry Volovye serdtce, Bahor and Revershon zoned in the Republic were used. As a rootstock for cherries, vegetatively propagated VVA-1 was used, and sweet cherries-VSL-2 (Krimsky-5).

The formation of the cherry crown was carried out according to the "fruit wall " type, with the formation of a crown with three and five-skeletal branches and their departure along the row, for cherries-a simple bowl, a KGB (Kim Green Bush), an Austrian Bush and a V-shaped one. The Central conductor above these branches was cut out. The left branches were subordinated in height, the thickening ones were cut out.

When forming a small-sized flat crown in the crown of trees, two well-developed skeletal branches were selected, directed along the row and horizontally fixed to wooden stakes during the first two years of growing plants. All other branches were deleted. In the spring of the following year, all vertical branches formed on the two main horizontal branches were limited in length by $60-70 \mathrm{~cm}$.

During the study period, the following physiological analyses were performed: determination of the leaf surface index, tree leaf area per 1 ha, and the content of chlorophyll species in the leaves. 


\section{RESULTS AND DISCUSSION}

An important morphological indicator of the active assimilation activity of leaves is the leaf surface index, expressed as the ratio of the leaf area to the crown projection. The higher this indicator is for trees, the more significant is the coefficient of photosynthetic activity of leaves for laying general tree formations, and, accordingly, obtaining high crop yields.

In our experiment, the leaf surface index was the highest, as expected, in the cherry variety Shpanka Chernaya (black), - up to $3.8 \mathrm{~m}^{2}$ of leaves per $\mathrm{m}^{2}$ of the crown projection area, which is on average 1.5 times more than in the control version using the cherry variety Shubinka.

From used artificial forms crown the best conditions to increase leaf area index of an individual tree was created for varieties of Shubinka in the embodiment of a flat wall, for the sorts Podbelskogo and Shpanka Chernaya (black), five-skeletal fruit wall, in which leaf area index were, respectively, 2,6; 3,7 and 4,4 $\mathrm{m}^{2}$ per square meter of crown projection of the tree (Table 1).

Table 1: Influence of the cherry crown formation system on the leaf surface index, $\mathrm{m} 2 \mathrm{of}$ leaves per $\mathrm{m} 2$ of crown projection area (2016-2019)

\begin{tabular}{|c|c|c|c|c|c|}
\hline \multirow{3}{*}{ Variety } & \multicolumn{5}{|c|}{ Crown form } \\
\hline & \multirow[b]{2}{*}{ Flat } & \multicolumn{3}{|c|}{ Fruit wall } & \multirow{2}{*}{$\begin{array}{l}\text { Sparse-tiered } \\
- \text { cont. }\end{array}$} \\
\hline & & $\begin{array}{l}\text { three- } \\
\text { skeletal }\end{array}$ & \begin{tabular}{|ll} 
five & - \\
skeletal
\end{tabular} & $\begin{array}{l}\text { Free- } \\
\text { growing }\end{array}$ & \\
\hline Shubinka & 2,6 & 2,5 & 2,4 & 2,6 & 1,8 \\
\hline Podbelskaya & 3,3 & 3,4 & 3,7 & 3,2 & 3,4 \\
\hline $\begin{array}{l}\text { Shpanka Chernaya } \\
\text { (black), }\end{array}$ & 3,8 & 3,8 & 4,4 & 3,4 & 2,9 \\
\hline $\mathrm{LSD}_{05}$ & 0,3 & 0,3 & 1,1 & 0,2 & 1,3 \\
\hline
\end{tabular}

Of the studied crown forms for growing cherries on low-growing rootstock VSL-2 (Krymsky5)using intensive technology, the highest rates of assimilation surface development per unit volume of the tree crown were noted when forming such crowns as V-shaped and KGB.

In these variants of the experiment, the index of leaf activity of sweet cherry trees was 3.3-4.6 $\mathrm{m} 2$ of leaves per square meter of the crown projection area. The increase in this physiological indicator to the control variant using the Revershon sweet cherry variety was 50.0-77.3, in the Volovye serdtce variety by 50.0-76.9 and in the Bahor variety by 58.3-75.0\% (Table 2). 
Table 2: Influence of the sweet cherry crown formation system on the leaf surface index, $\mathrm{m} 2$ of leaves per $\mathrm{m} 2$ of crown projection area (2016-2019)

\begin{tabular}{|l|l|l|l|}
\hline \multirow{2}{*}{ Crown forms } & \multicolumn{2}{|l|}{ Varieties } & \multicolumn{2}{|l|}{} \\
\cline { 2 - 4 } & Revershon & Volovye serdtce & Bahor \\
\hline Simple bowl - cont. & 2,2 & 2,6 & 2,4 \\
\hline KGB & 3,3 & 3,9 & 3,8 \\
\hline Austrian Bush & 2,6 & 3,1 & 2,8 \\
\hline V-shaped & 3,9 & 4,6 & 4,2 \\
\hline LSD 05 & 0,3 & 0,5 & 0,3 \\
\hline
\end{tabular}

Experimental material and analysis of experimental data shown in table 3 shows that varietal morphological features and the structure of the cherry crown shape have a significant impact not only on the individual leaf apparatus of plants, but also on the subsequent correct choice of the tree placement scheme in the garden. This is especially important for plants grown using intensive technology. The area of leaves of cherry trees placed on a unit of garden area reached the maximum value in the variants of artificial crown formation - a flat crown and a fruit wall with up to five-skeletal branches left in the crown. In these variants, the assimilation surface of the leaves reached a value of 16.21 and 17.43 thousand $\mathrm{m}^{2} /$ ha for Shubinka and Podbelskaya varieties, and 39.01 thousand $\mathrm{m}^{2} /$ ha for Shpanki Chernaya (black), which is 2.4 times more than for the above cherry varieties. This indicates that the cherry variety Shpanka, grown on a vegetatively propagated rootstock VVA-1, is most suitable for laying gardens grown using intensive technology (Table 3).

Table 3: Influence of the cherry crown formation system on the assimilation surface of leaves, thousand $\mathrm{m}^{2} / \mathrm{ha}$. (2016-2019).

\begin{tabular}{|l|l|l|l|l|l|}
\hline \multirow{2}{*}{ Variety } & \multicolumn{4}{l|}{ Crown forms } & \multirow{2}{l}{$\begin{array}{l}\text { Sparse-tiered } \\
\text { - cont. }\end{array}$} \\
\cline { 2 - 6 } & \multirow{2}{*}{ Flat } & \multicolumn{2}{l|}{ Fruit wall } \\
\cline { 3 - 6 } & & $\begin{array}{l}\text { three- } \\
\text { skeletal }\end{array}$ & $\begin{array}{l}\text { five } \\
\text { skeletal }\end{array}$ & $\begin{array}{l}\text { Free- } \\
\text { growing }\end{array}$ & \\
\hline Shubinka & 16,21 & 10,74 & 15,69 & 11,65 & 7,54 \\
\hline Podbelskaya & 16,95 & 16,90 & 17,43 & 19,34 & 7,87 \\
\hline Shpanka & 33,13 & 36,83 & 39,01 & 31,83 & 15,89 \\
\hline
\end{tabular}




\begin{tabular}{|l|l|l|l|l|l|}
\hline Chernaya(black) & & & & & \\
\hline LSD $_{05}$ & 0,7 & 3,4 & 1,8 & 4,7 & 0,21 \\
\hline
\end{tabular}

Of the methods of forming the crown of sweetcherry trees grown on a low-growing vegetatively propagated rootstock VSL-2 (Krymsky-5), the most developed aboveground part and leaf surface area per unit area of the garden was the Volovye serdtce variety, the lesser development was noted in the Revershon variety. The Bahor variety had an intermediate position in this physiological indicator.

As shown by the experimental data shown in table 8 , the maximum assimilation surface of leaves per unit area of the garden of the second world war in cases of formation was the sweet cherry variety Volovye serdtce 28.64-57.90 thousand $\mathrm{m}^{2} / \mathrm{ha}$. The formation of the minimum assimilation surface of leaves was observed when using the $\mathrm{V}$-shaped crown formation of trees of 25.99-28.64 thousand $\mathrm{m}^{2} / \mathrm{ha}$ (Table 4 ).

Table 4: Influence of the cherry crown formation system on the assimilation surface of leaves, thousand $\mathrm{m}^{2} / \mathrm{ha}(2016-2019)$

\begin{tabular}{|l|l|l|l|}
\hline \multirow{2}{*}{ Crown forms } & \multicolumn{2}{|l|}{ Varieties } \\
\cline { 2 - 4 } & Revershon & Volovye serdtce & Bahor \\
\hline Simple bowl - cont. & 36,77 & 57,90 & 55,15 \\
\hline KGB & 45,15 & 49,77 & 47,40 \\
\hline Austrian Bush & 43,72 & 48,19 & 45,90 \\
\hline V-shaped & 25,99 & 28,64 & 27,28 \\
\hline LSD 05 & 1,3 & 0,4 & 1,4 \\
\hline
\end{tabular}

The formation of the crown of trees in the form of KGB and the Austrian Bush provided the development of the assimilation surface of leaves from 43.72 to 49.77 thousand $\mathrm{m}^{2} / \mathrm{ha}$.

From the conducted research it is clear that practically all methods of artificial formation of the crown of sweet cherry trees have a positive effect on the formation of the assimilation surface by sweet cherry varieties. The exception is the V-shaped crown method, in which trees form the smallest leaf area 25.99-28.64 49.77 thousand $\mathrm{m}^{2} / \mathrm{ha}$. 


\section{CONCLUSIONS}

Studied artificial forms of cherry crown optimum is three- and five- planar skeletal forms, sweet cherries forming by method of the KGB and Austrian Bush, in which the leaf area of an individual tree reaches respectively $27,3-29,2 \mathrm{~m}^{2}$, of $24.7429 .2 \mathrm{~m}^{2} /$ tree, up $27.2 \%$ more than the generally accepted in the Republic of sparsely-tier forming trees.

\section{REFERENCES}

Abrorov Sh. Modern intensive sweet cherry gardens. Tashkent: Baktria press, (2018).

Kudryavets R.P. New highly productive tree crowns. Moscow, Moscow University. (1974). p. 80.

Lukin E.S., Degtyareva O.A. Technological study of cherries.- Improvement of assortment and technology of cultivation of stone fruit crops. Orel, VNIISPK, (1998). pp. 129-131.

Senin V.I., Kovaleva A.F. New in intensive gardening. Dnepropetrovsk, Promin, (1984). pp. 135139.

Trusevich G.V. Efficiency of thickened plantings. Gardening, (1970), No. 10, pp. 11-12.

Sanavini S. Ia fruticultura Italiana degli anni 80: Aspetti agronomici c produttivi. (S. Sansavini) rivista di Fruticaltura. (1984). Vol. 4, No.6, pp. 8-30. 